\title{
Reproductive biology of the spiny eel Macrognathus pancalus Hamilton, 1822 from upper Assam, India
}

\author{
S. K. ABUJAM* AND S. P. BISWAS \\ *Department of Zoology, Rajiv Gandhi University, Rono Hills, Doimukh, Itanagar - 791 112, Arunachal Pradesh, India \\ Department of Life Sciences, Dibrugarh University, Dibrugarh - 786 004, Assam, India \\ e-mail: santosh.abujam@gmail.com
}

\begin{abstract}
Reproductive biology of spiny eel Macrognathus pancalus Hamilton, 1822 was studied from the waterbodies of upper Assam, India. Sexual dimorphism was easily distinguished based on their body shape and colouration. Among the 467 fish samples examined, 312 males and 155 females were identified and the Male:Female (M:F) ratio ranged from 1:0.08 in November to 1:2.17 in June with overall sex ratio of 1:0.5. Five maturity stages were identified in a year and percentage distribution of each stage was calculated. The gonadosomatic index (GSI) ranged from 0.42 to 8.08 for females and from 0.33 to 1.25 for males. The length at $50 \%$ of the fishes attained maturity $\left(\mathrm{Lm}_{50}\right)$ was $9-12 \mathrm{~cm}$ in males and at $12-15 \mathrm{~cm}$ in females, indicating males matures at moderately smaller size than their female counterparts. Ova diameter ranged from 0.3 to $1.3 \mathrm{~mm}$; absolute fecundity ranged from 765.48 to 1691.96 and relative fecundity from 57.9 to 152.17 . M. pancalus spawned once in a year with peak spawning between June and August.
\end{abstract}

Keywords: Indian spiny eel, Macrognathus pancalus, Reproductive biology, Upper Assam

\section{Introduction}

Macrognathus pancalus Hamilton, 1822 commonly known as 'striped spiny eel' or 'barred spiny eel' is widely distributed in the Ganges and Brahmaputra river basins in India, Bangladesh, Nepal and Pakistan (Talwar and Jhingran, 1991; Froese and Paully, 2006). They generally live in sluggish and shallow waterbodies of plains such as canals, wetlands, ponds as well as inundated fields and also found in streams, rivers and estuaries. The spiny eels are delicious, excellent food fishes and occasionally kept as pets in aquarium and widely accepted in the Asian subcontinent (Nelson, 1994; Narejo et al., 2002). Further, spiny eels have gained importance for its ornamental value as a native aquarium fish in India and are being exported to other Asian countries, Europe and America (Tripathi, 2004). The species is economically important and palatable as a table fish and demand for the fish virtually always exceeds its supply, especially in northern and eastern areas of India where people relish live and less bony fish (Narejo et al., 2002; Abujam and Biswas, 2011). M. pancalus fetches high market price (₹240-260 per kg) particularly in local markets of upper Assam, India especially when sold alive.

It might be mentioned that the population of this spiny eel is rapidly dwindling in the Indian sub-continent, as perceived from decreasing market arrivals, due to habitat alteration and overexploitation (Lakra and Sarkar, 2006). Unregulated exploitation might endanger their wild population in near future. So far, there has been very limited work on the reproductive biology of fishes belonging to the genus Macrognathus throughout the world. Swarup et al. (1972) studied sexual dimorphism in M. pancalus while, Karim and Hossain (1972) investigated on certain aspects of reproductive biology of $M$. pancalus in artificial ponds. Later, Suresh et al. (2006) worked out certain aspects of general biology of $M$. pancalus from Ganga River. Abujam and Biswas (2011) studied some aspects of reproductive biology of Macrognathus aral from the waterbodies of upper Assam. However, no comprehensive work has so far been done on the reproductive biology of $M$. pancalus from the north-eastern states of India.

In this backdrop, a detailed study on the different aspects of reproductive biology of $M$. pancalus was taken from the waterbodies of upper Assam, India in order to generate baseline information for future propagation through captive breeding programmes.

\section{Materials and methods}

Study site and collection of fish specimens

Specimens of $M$. pancalus were collected from the

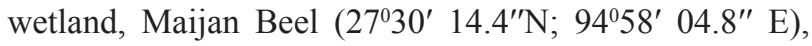
about $15 \mathrm{~km}$ east of Dibrugarh and Guijan Ghat $\left(27^{\circ} 34^{\prime}\right.$ 39.4"N; 94019' 29.60"E) in Tinsukia District, Assam, India between 2010 and 2011 (Fig. 1a, b). The wetland was formed in a former channel of Brahmaputra River (oxbow lake), covering an area of 134 ha and its elevation 


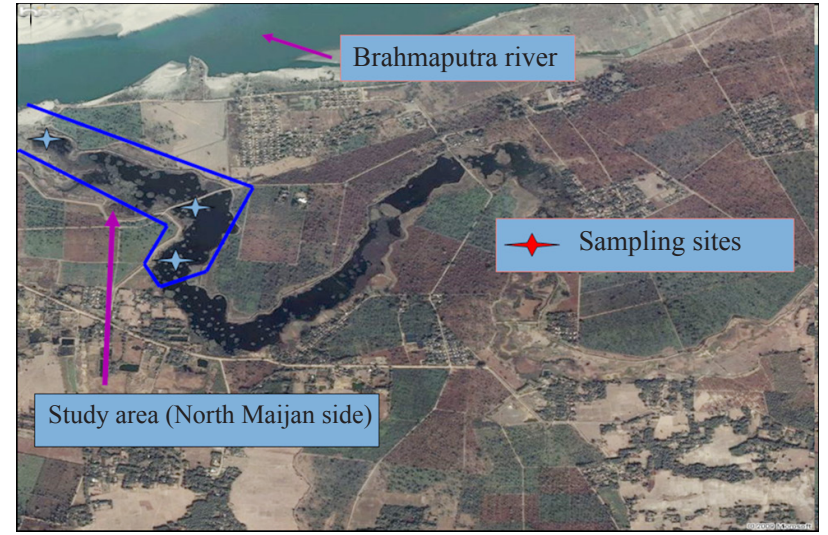

(a)

Fig. 1. (a) Satellite imagery of study site, (b) Maijan Beel.

ranged from 86 to $102 \mathrm{~m}$; the maximum and minimum depths being 9 and $3 \mathrm{~m}$ respectively. The water body is completely surrounded by tea garden and there is a small connecting channel with the Brahmaputra River. The Guijan Ghat is located at the bank of Brahmaputra River. Altogether, 467 specimens of M. pancalus were collected on monthly basis from the sampling sites. The total weight, length, sex and gonadal maturity stages were recorded and then preserved in $10 \%$ formalin for further investigations.

\section{General reproductive biology}

After collection of the specimens from their natural habitat, at least 15-20 specimens were randomly selected every month for studying their gonadal development and related aspects. Before dissecting out the gonads, the length and weight as well as morphological features (colouration) of individual specimens were recorded.

Sexual dimorphism and sex ratio: Sexual dimorphism of M. pancalus was confirmed following Talwar and Jhingran (1991). The sex ratio was articulated as the proportion of males to the sum of the sampled specimens. Sex ratio was analysed using Chi-square test $\left(\mathrm{X}^{2}\right)$ following Fisher (1970), assuming that the ratio of male to female in the population to be 1:1.

Maturity stages: The seasonal progressions of gonadal maturity stages were determined following the key as outlined by Lelek (1993).

Gonadosomatic index (GSI): In order to study the condition of the gonads and estimation of spawning season, the GSI was calculated using the formula (Hopkins, 1979; Biswas, 1993):

$$
\text { GSI }=\frac{\text { Gonad weight }}{\text { Total body weight }} \times 100
$$

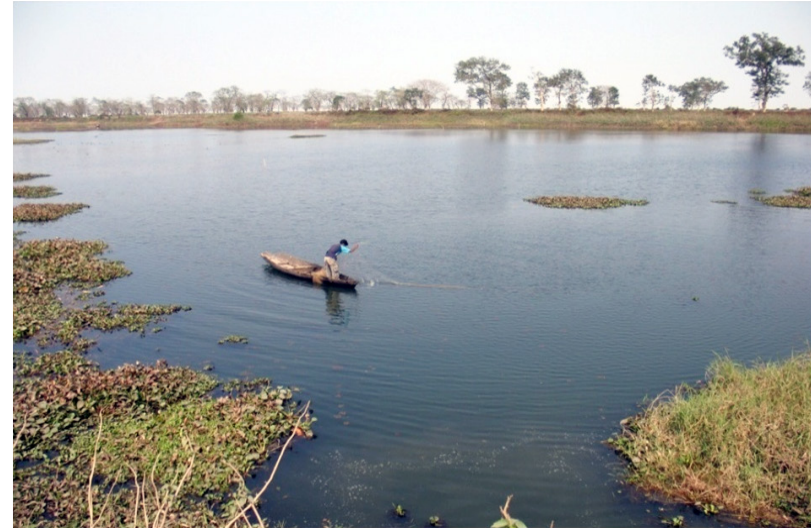

(b)

Length at first maturity: The percentage of mature fish (stage III to V) was examined for each length group of both sexes of the species. The size (in length) at which $50 \%$ of the population attains maturity $\left(\mathrm{Lm}_{50}\right)$ was calculated as per Hodgkiss and Mann (1978) and it was arrived by plotting the percentage of mature specimens (stage IV and above) against total length of the fish (Biswas, 1993).

Ova diameter: Ova diameter measurements were carried out from formalin preserved materials. Random sub-samples were taken from individual ovary (anterior, middle and posterior parts) and subjected to ova diameter measurement using an ocular micrometer. The diameters of ova along whatever axes they lay parallel to the graduation of the micrometer, were measured to ensure random nature of the readings (Biswas, 1993).

Absolute fecundity (AF): Ovaries from maturing, mature and ripe specimens (collected just before breeding) were used for determination of fecundity. Sub-sampling of ovaries using weight method of Bagenal and Braum (1978) and Grimes and Huntsman (1980) was done and after drying off the excess moisture with the help of a blotting paper, fecundity was calculated from the counts of ova in sub-samples (randomly) of known weight:

$$
\mathrm{F}=\frac{\mathrm{nG}}{\mathrm{g}}
$$

where, $\mathrm{F}=$ fecundity; $\mathrm{G}=$ weight of the ovary; $\mathrm{n}=$ number of eggs in sub-sample; $\mathrm{g}=$ weight of the sub-sample.

Relative fecundity (RF): The relative fecundity was calculated using standard formula of Grimes and Huntsman (1980):

$$
\text { Relative fecundity }=\frac{\text { Total no. of eggs in the ovary (AF) }}{\text { Body weight }(\mathrm{g})}
$$


The relationship between (a) fecundity and total length; (b) fecundity and body weight and (c) fecundity and ovary weight were calculated and $\log$ to $\log$ relationship in the form given below (Bagenal, 1978) has been followed: $\log \mathrm{F}=\log \mathrm{a}+\mathrm{b} \log \mathrm{X}$.

where; $\mathrm{F}=$ fecundity, $\mathrm{X}=$ variable factors like body length, weight and ovary weight, 'b' = exponential value and ' $a$ ' = constant.

Spawning period: The spawning period was determined following the standard procedure of Biswas (1993).

\section{Results and discussion}

\section{Sexual dimorphism and sex ratio}

M. pancalus is a dieocious fish but secondary sex characters are wanting. The sexes cannot easily be recognised externally outside the spawning periods except by dissection. Generally the females are larger to some extent than males of the similar age. Body is eel like, with a series of separate and tiny strong spines on their back. Body is greenish or olive-green above and yellowish or whitish below. A light press on the abdomen of ripe fish release the whitish milt from males and eggs from females (Fig. 2a, b). Skin of the spiny eel is covered with tiny scales. The male: female sex ratio varied from 1:0.08 (November) to 1:2.17 (June). Among the 467 fish samples studied, 312 males and 155 females were identified indicating the overall $\mathrm{M}: \mathrm{F}$ ratio as 1:0.5 (Table 1). The monthly sex ratio showed that there was significant deviation from the usual 1:1 ratio and the ratio tilted towards males in most of the months. The males become active and brighter in colour while females more pot bellied and dull during breeding season. Generally, sex ratios of fishes have been considered vital in fisheries and sex ratio is generally close to 1:1 (Swarup et al., 1972). However, the sex ratio estimated during different

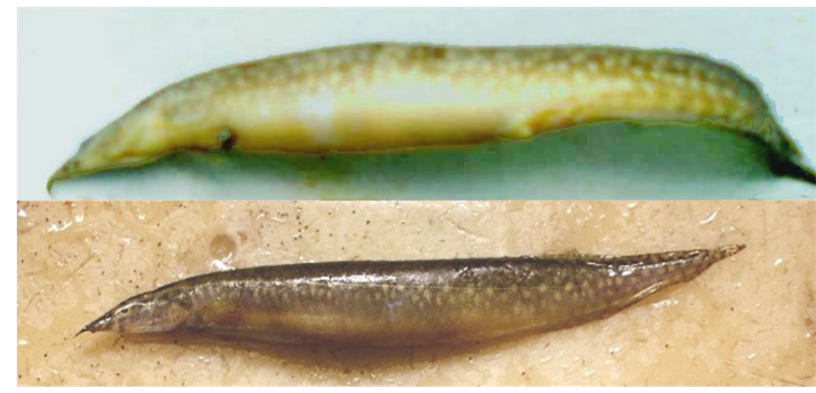

(a)

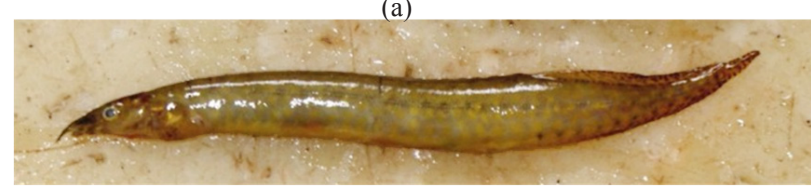

(b)

Fig. 2. Macrognathus pancalus (a) Female, (b) Male

months reveals wide variation in M. pancalus. The overall $\mathrm{M}: \mathrm{F}$ ratio indicated a highly skewed distribution of sexes. The overall sex ratio (pooled) varied significantly from the usual $1: 1$ ratio $(\mathrm{p}<0.01)$. Due to their different size, ecological condition and niche occupied, probably females escape the fishing gear more often and therefore less females were encountered during the catch. Sex ratio indicated dominance of males throughout the year. Similar observation was recorded by Abujam and Biswas (2011) in Macrognathus aral. Sex ratio deviation has also been reported in other fish species (Wu and Kuo, 1993; Ramon and Bailey, 1996). However, Swarup et al. (1972), reported a sex ratio of 1:1 in M. pancalus.

\section{Maturity stages}

Five maturity stages were identified in $M$. pancalus (Table 2; Fig. 3, 4) depending on gonad structure, area occupied by gonads in the abdominal cavity and

Table 1. Monthly variation in sex ratio (M: F) of M. pancalus

\begin{tabular}{llllll}
\hline Months & Males (no.) & Females (no.) & Sexes pooled (no.) & Sex ratio & Chi-square value \\
\hline Jan. & 30 & 2 & 32 & $1: 0.7$ & $24.5^{*}$ \\
Feb. & 26 & 12 & 38 & $1: 0.46$ & $5.16^{*}$ \\
Mar. & 22 & 15 & 37 & $1: 0.68$ & 1.32 \\
Apr. & 21 & 18 & 39 & $1: 0.86$ & 0.23 \\
May & 14 & 23 & 37 & $1: 1.64$ & 2.19 \\
Jun. & 12 & 26 & 38 & $1: 2.17$ & $5.16^{*}$ \\
Jul. & 16 & 26 & 42 & $1: 1.63$ & 2.38 \\
Aug. & 24 & 16 & 40 & $1: 0.67$ & 1.6 \\
Sep. & 34 & 5 & 39 & $1: 0.15$ & $21.56^{*}$ \\
Oct. & 39 & 4 & 43 & $1: 0.1$ & $28.29^{*}$ \\
Nov. & 38 & 3 & 41 & $1: 0.08$ & $29.88^{*}$ \\
Dec. & 36 & 5 & 41 & $1: 0.14$ & $33.44^{*}$ \\
Pooled & 312 & 155 & 467 & $1: 0.5$ & $52.78^{*}$ \\
\hline
\end{tabular}

*Significant at $\mathrm{p}<0.05$ 
Table 2. Gonadal maturity stages in M. pancalus

\begin{tabular}{lll}
\hline Maturity stages & Ovary & Testes \\
\hline Stage I (Immature) & $\begin{array}{l}\text { Small, thin, occupy } 1 / 4^{\text {th }} \text { of the body cavity, thick ribbon } \\
\text { shaped, light pink in colour, opaque, transparent. Ova are not } \\
\text { distinct to the naked eyes }\end{array}$ & $\begin{array}{l}\text { Very small, thin, slender, transparent to } \\
\text { colourless, threadlike, closely adherent to } \\
\text { dorsal wall of the abdominal cavity }\end{array}$ \\
Stage II (Maturing) & $\begin{array}{l}\text { Occupy half of the body cavity and broader than stage I, } \\
\text { thick ribbon shaped with dark pink or red colour and granular } \\
\text { appearance }\end{array}$ & $\begin{array}{l}\text { Translucent, wider than stage I, silvery, filling } \\
\text { half dorsal ventral cavity }\end{array}$ \\
Stage III (Mature) & $\begin{array}{l}\text { Occupy } 3 \text { /th }^{\text {th }} \text { of the body cavity, much broader than stage I } \\
\text { and II; shape rounded, colour dark orange/pale yellow with } \\
\text { conspicuous superficial blood vessels; ova large, opaque and } \\
\text { visible to the naked eyes }\end{array}$ & $\begin{array}{l}\text { Opaque, enlarged, firm, drops of milt may fall } \\
\text { under pressure and dull white in colour }\end{array}$ \\
& $\begin{array}{l}\text { Occupy the entire body cavity; eggs completely rounded, } \\
\text { laden with yolk and spherical; orange/yellow coloured; } \\
\text { ovarian wall very thin and translucent }\end{array}$ & Soft, milt ran with slight pressure \\
Stage IV (Ripe) & $\begin{array}{l}\text { Ovaries flabby, shrunken, further contracted, appear like } \\
\text { wrinkled, larger eggs absent }\end{array}$ & $\begin{array}{l}\text { Very thin, slightly less rigid, flabby, reddish } \\
\text { with blood capillaries }\end{array}$ \\
\hline
\end{tabular}

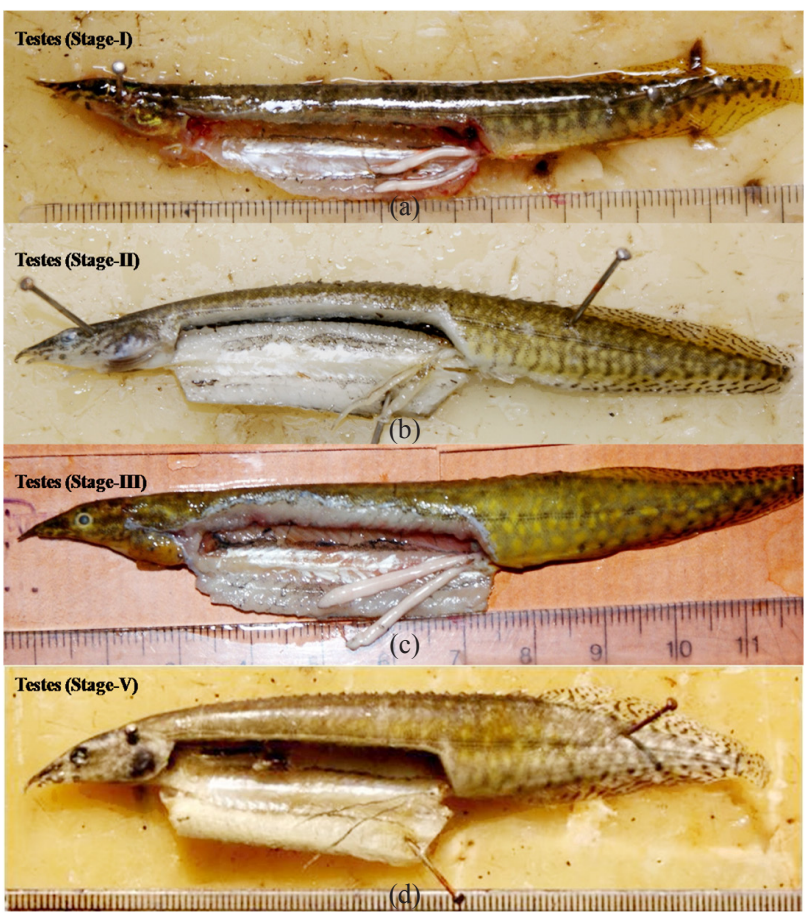

Fig. 3. Maturity stages of testes in M. pancalus. (a) stage I, (b) stage II, (c) stage III, (d) stage IV

diameter of unspawned eggs. It was observed that most of the stages occurred throughout the year. The monthly percentage distribution of various maturity stages in males and females are given in Table 3. Immature females (70.5\%) occurred during February to March while maturing females (44.81\%) were encountered from March to June. Further, mature females $(40.8 \%)$ were available from April to August and ripe females (34.14\%) were recorded from July to August. Immature (26.7\%) and

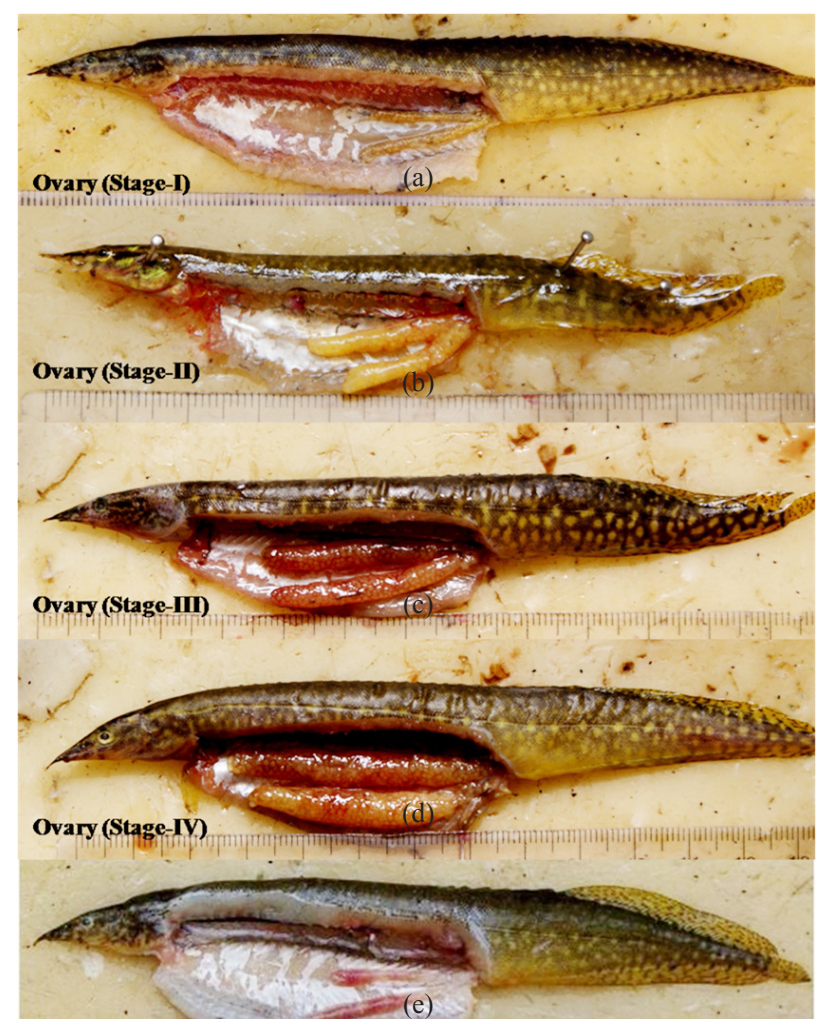

Fig. 4. Maturity stages of ovary in M. pancalus. (a) stage I, (b) stage II, (c) stage III, (d) stage IV, (e) stage V

maturing (54.69\%) males were observed from January/ February to June. Mature (38.91\%) and ripe (27.08\%) males were encountered from May/June to August. Spent males were recorded during September to January with peak occurrence in November $(65.46 \%)$. Majority of males $(65.46 \%)$ and females $(87 \%)$ of $M$. pancalus were approaching the spent stage by September to January. 
Table 3. Percentage occurrence of different maturity stages in males and females of M. pancalus

\begin{tabular}{|c|c|c|c|c|c|c|c|c|c|c|c|c|}
\hline \multirow[t]{2}{*}{ Month } & \multirow{2}{*}{$\begin{array}{l}\text { No. of males } \\
\text { examined }\end{array}$} & \multicolumn{5}{|c|}{ Maturity stages } & \multirow{2}{*}{$\begin{array}{l}\text { No. of females } \\
\text { examined }\end{array}$} & \multicolumn{5}{|c|}{ Maturity stages } \\
\hline & & I & II & III & IV & $\mathrm{V}$ & & I & II & III & IV & $\mathrm{V}$ \\
\hline Jan & 30 & 33.33 & 36.67 & - & - & 30.0 & 2 & - & - & - & - & 100 \\
\hline Feb & 26 & 26.92 & 53.85 & - & - & 19.23 & 12 & 75.0 & 25.0 & - & - & - \\
\hline Mar & 22 & 22.72 & 63.64 & 13.64 & - & - & 15 & 66.0 & 33.33 & 6.67 & - & - \\
\hline Apr & 21 & 23.81 & 57.14 & 19.05 & - & - & 18 & 11.11 & 61.11 & 27.78 & - & - \\
\hline May & 14 & 14.29 & 57.14 & 28.57 & - & - & 23 & 8.7 & 34.78 & 56.52 & - & - \\
\hline Jun & 12 & 8.33 & 41.67 & 33.33 & 16.67 & - & 26 & - & 50.0 & 38.46 & 11.54 & - \\
\hline Jul & 16 & - & 12.5 & 56.25 & 31.25 & - & 26 & - & 19.23 & 50.0 & 30.77 & - \\
\hline Aug & 24 & - & 20.84 & 37.5 & 33.33 & 8.33 & 16 & - & 18.75 & 31.25 & 37.5 & 12.5 \\
\hline Sep & 34 & - & 29.41 & 11.76 & - & 58.83 & 5 & - & - & 20.0 & 20.0 & 60.0 \\
\hline Oct & 39 & 17.95 & - & - & - & 82.05 & 4 & - & - & 25.0 & - & 75.0 \\
\hline Nov & 38 & 15.79 & - & - & - & 84.21 & 3 & - & - & - & - & 100 \\
\hline Dec & 36 & 16.67 & 11.11 & - & - & 72.22 & 5 & - & - & - & - & 100 \\
\hline
\end{tabular}

Fully mature and ripe ovary of $M$. pancalus occupies nearly whole of the body cavity and both the lobes of gonads are slightly unequal in their length. The gonads appear as a pair of elongated strap lying in the body cavity one on each side of the intestine. Mature ovaries contain large and orange coloured eggs. Qasim (1973) opined that the classification of gonads should be limited to about 5 maturity stages in tropical and subtropical fishes. Nautiyal and Lal (1985) also described five maturity stages (I-V) in riverine and reservoir fish populations. Morphologically, immature testes did not differ much from the immature ovaries either in shape or size except that they were cream coloured. The testes, however, do not occupy the body cavity as much as the ovaries. The mature testes, unlike mature ovaries, were fringed and filled with milky seminal fluid.

A perusal of the data on the occurrence of maturity stages revealed that most of the stages are represented throughout the year. Immature male for M. pancalus, were available during January to May and again reappeared from October onwards while immature females were recorded from February to May. Maturing males were also observed from January to June while maturing females were noticed from February to June. Number of maturing fishes dropped down from July onwards in both the sexes. Highest percentage occurrence for mature males and females were available during March to August while ripe males and females were encountered during June to August/September. Further, occurrence of mature fishes declined from September while, ripe fishes were not observed from October to May. It appears that M. pancalus breeds/spawns from June to September. This is further supported by higher occurrence of spent females and males during September to January. Thus, it could be inferred that the spawning was over by September.

\section{Gonadosomatic index (GSI)}

The monthly average variation in gonadosomatic index (GSI) in both sexes of $M$. pancalus is given in Table 4. The GSI for females ranged from $0.42 \pm 0.05$ to $8.08 \pm 2.85$ during January and June respectively. Similarly, for males it varied between $0.33 \pm 0.12$ and $1.25 \pm 0.57$ during October and May. With respect to maturity stages, the highest $(7.91 \pm 2.34)$ and lowest $(0.79 \pm 0.37)$ GSI values for females was found in ripe and spent stages while in case of males, the highest $(1.17 \pm 0.39)$ and lowest $(0.34 \pm 0.39)$ values were recorded in ripe and spent stages respectively (Table 5 ).

Table 4. Monthly mean variations in gonadosomatic index (GSI) in M. pancalus (Mean \pm S.D.)

\begin{tabular}{lll}
\hline Month & Male & Female \\
\hline Jan & $0.56( \pm 0.22)$ & $0.42( \pm 0.05)$ \\
Feb & $0.64( \pm 0.21)$ & $1.82( \pm 0.66)$ \\
Mar & $0.89( \pm 0.49)$ & $1.49( \pm 0.76)$ \\
Apr & $1.03( \pm 0.50)$ & $7.15( \pm 2.79)$ \\
May & $1.25( \pm 0.57)$ & $5.97( \pm 2.04)$ \\
Jun & $0.87( \pm 0.31)$ & $8.08( \pm 2.85)$ \\
Jul & $1.21( \pm 0.24)$ & $7.75( \pm 2.24)$ \\
Aug & $0.51( \pm 0.14)$ & $6.87( \pm 2.2)$ \\
Sep & $0.38( \pm 0.14)$ & $5.90( \pm 2.35)$ \\
Oct & $0.33( \pm 0.12)$ & $4.67( \pm 1.54)$ \\
Nov & $0.45( \pm 0.17)$ & $0.97( \pm 0.09)$ \\
Dec & $0.49( \pm 0.19)$ & $0.68( \pm 0.08)$ \\
\hline
\end{tabular}

Table 5. Variations in GSI during different maturity stage of M. pancalus (mean \pm S.D.)

\begin{tabular}{lll}
\hline Maturity stage & Male & Female \\
\hline Immature (Stage I) & $0.53( \pm 2.04)$ & $1.48( \pm 0.48)$ \\
Maturing (Stage II) & $0.62( \pm 0.29)$ & $6.66( \pm 2.72)$ \\
Mature (Stage III) & $1.17( \pm 0.39)$ & $7.91( \pm 2.34)$ \\
Ripe (Stage IV) & $0.73( \pm 0.31)$ & $9.36( \pm 2.34)$ \\
Spent (Stage V) & $0.34( \pm 0.13)$ & $0.79( \pm 0.37)$ \\
\hline
\end{tabular}


In the present study, the higher GSI values for males were observed during March-July/August (with peak in May) which subsequently decreased from September onwards and became very low in October/November. In case of females, GSI increased from February/March to September with peak in June, which was coinciding with the peak breeding season and indicating commencement of active breeding during May to August. This indicates a prolonged breeding season which started decreasing from October onwards. The observation was similar with those of Islam (2004), Vinci et al. (2005) and Annappaswamy et al. (2008) in different fish species.

The highest and lowest GSI values for females and males were recorded in ripe (stage IV) and spent (stage V) stages. The GSI increases with maturity of gonads in both sexes of the species. Abujam and Biswas (2011) also observed that GSI increases with maturity of fish, with the the highest values observed during the period of peak breeding which abruptly decreases thereafter, during the spent stage. Komolafe and Arawomo (2007) also reported higher GSI values in ripe stages of Oreochromis niloticus and the GSI values decreased during spent stage. The highest GSI in ripe stage suggests that the ovary has maximum percentage of yolk during this stage. The GSI values of males were always lower than those of the females of M. pancalus. After spawning period, there were only fewer or no eggs in the female gonads. The GSI values later increased further in immature stages, giving indication of continuity of maturing process in the species. The results indicate that $M$. pancalus spawns once in a year.

\section{Length at first maturity and $\mathrm{Lm}_{50}$ determination}

As far as size at first maturity and length at $50 \%$ of the fishes attain maturity $\left(\mathrm{Lm}_{50}\right)$ determination was concerned, both males and females in stage III - IV of maturation were considered as mature (Raje, 2006). The percentages of immature, maturing, mature and ripe gonads for each length group of M. pancalus were calculated separately (Table
6). The results indicated that $100 \%$ males were immature in $6.0-9.0 \mathrm{~cm}$ length group; and in the in the $9-12 \mathrm{~cm}$ length group, $30.82 \%$ of maturing, $50.31 \%$ of mature/ ripe males and $62.79 \%$ immature and $37.21 \%$ maturing females were observed. In $12-15 \mathrm{~cm}$ size group, maturing $(30.66 \%)$ and mature/ripe $(65.46 \%)$ males, whereas maturing (40.78\%) and mature /ripe (53.87\%) females were observed, Similarly, in $15-18 \mathrm{~cm}$ group, mature/ripe males $(90.0 \%)$ and females $(84.57 \%)$ were found while $100 \%$ mature/ripe males and females were observed in $18-21 \mathrm{~cm}$ length group. The data suggest that $50 \%$ of the fishes attained maturity $\left(\mathrm{Lm}_{50}\right)$ in the length group of $9-12 \mathrm{~cm}$ in males and $12-15 \mathrm{~cm}$ in females, indicating that males mature at smaller size than their female counterparts (Fig. 5). The calculated mean size at first maturity was $10.5 \mathrm{~cm}$ for males and $13.5 \mathrm{~cm}$ for females.

Present findings show slight deviation from the observations made by Suresh et al. (2006) who reported that in $M$. pancalus males attained $50 \%$ maturity at $10-11 \mathrm{~cm}$ and females at $11-12 \mathrm{~cm}$. The difference could

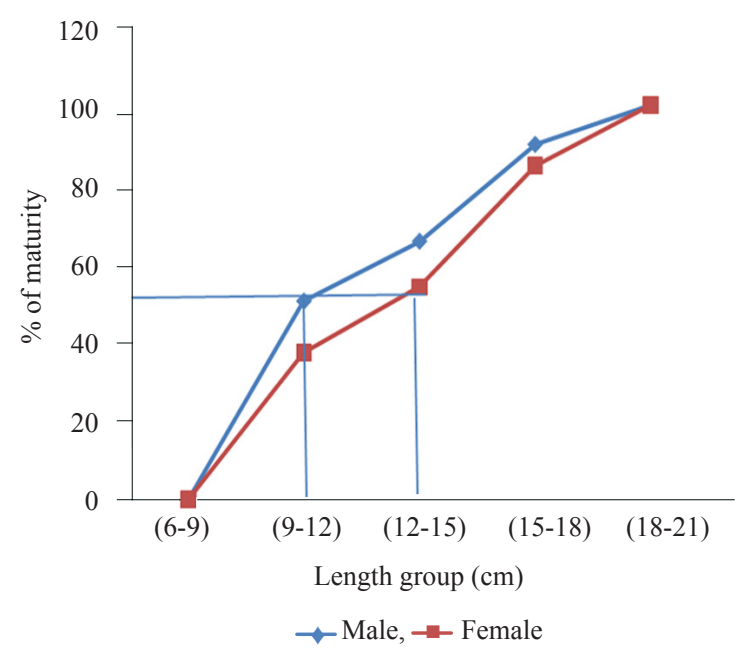

Fig. 5. Length at $50 \%$ of the fishes attain maturity $\left(\mathrm{Lm}_{50}\right)$ in M. pancalus

Table 6. Percentage of different maturity stages in different length groups of M. pancalus

\begin{tabular}{lllll}
\hline Standard length group $(\mathrm{cm})$ & Sex & Immature \% (Stage I) & Maturing \% (Stage II) & Mature/Ripe \% (Stage III\&IV) \\
\hline $6-9$ & Male & 100 & - & - \\
& Female & - & - & - \\
\hline $9-12$ & Male & 18.87 & 30.82 & 50.31 \\
& Female & 62.79 & 37.21 & - \\
\hline $12-15$ & Male & 3.88 & 30.66 & 65.46 \\
& Female & 5.35 & 40.78 & 53.87 \\
\hline $15-18$ & Male & - & 10.0 & 90.0 \\
& Female & - & 15.43 & 84.57 \\
\hline $18-21$ & Male & - & - & 100 \\
& Female & - & - & 100 \\
\hline
\end{tabular}


be attributed to different climatic conditions that exist in Ganga and Brahmaputra basins. There may also be a delay in attaining sexual maturity at higher mean sea levels for this species. A close relationship between maturity and length of the fish has been reported by El-Halfawy (2004); Sahayak (2005) and Al-Nahdi et al. (2010). From the observations on length at maturity, it was evident that males mature at small length size than their female counterparts of $M$. pancalus.

\section{Ova diameter}

The monthly progression of mean ova diameter of M. pancalus is shown in Table 7. Ovary of maturing females was light orange in colour while the eggs of ripe fish were large yellowish/light greenish in colour. The ova diameter gradually increased from $0.3 \mathrm{~mm}$ (February) to $1.3 \mathrm{~mm}$ (June-August). Immature ova were having diameter of $0.3-0.6 \mathrm{~mm}$ and were mostly found from February to May. Maturing ova (0.5-0.9 mm) and mature ova (0.7-1.1 mm) were mostly encountered between March and October while ripe ova $(8-1.3 \mathrm{~mm})$ between May and August. The mature and ripe ova of spiny eels are round or spherical and uniform in diameter, indicating that the eggs shed in a single batch during the peak spawning period from May to July. The fully spent ovary had only a few immature ova left and this stage was mostly encountered from October onwards till February.

The ova diameter progressively increased between February/March and August/September. Occurrence of larger sized ova indicated that peak breeding took place during May to August. Similar observations were also reported in Macrognathus aculeatus (Nabi and Hussain, 1996) and in M. pancalus (Suresh et al., 2006). Occurrence of maturing and mature ova progressively reduced from October onwards and these stages were absolutely absent from November to February. Further, it was also observed
Table 7. Monthly progression of mean ova diameter (OD) in M. pancalus (mean \pm S.D.)

\begin{tabular}{lll}
\hline Month & Range of OD & Mean OD \\
\hline January & - & - \\
February & $0.3-0.9$ & $0.60 \pm 0.13$ \\
March & $0.4-1$ & $0.70 \pm 0.14$ \\
April & $0.5-1.2$ & $0.85 \pm 0.12$ \\
May & $0.5-1.2$ & $0.85 \pm 0.13$ \\
June & $0.5-1.3$ & $0.90 \pm 0.12$ \\
July & $0.6-1.3$ & $0.95 \pm 0.14$ \\
August & $0.6-1.3$ & $0.95 \pm 0.13$ \\
September & $0.5-1$ & $0.80 \pm 0.04$ \\
October & $0.5-1$ & $0.75 \pm 0.07$ \\
November & - & - \\
December & - & - \\
\hline
\end{tabular}

that the fish has probably a longer spawning period, extending from March to September.

\section{Fecundity.}

The absolute fecundity ranged from $765.48 \pm 231.68$ (March) to 1691.96 \pm 932.1 (August) and relative fecundity from $57.9 \pm 11.8$ (February) to $152.17 \pm 44.73$ (July) (Table 8). The highest fecundity (1691.96) was found from a fish measuring $14.54 \pm 2.58 \mathrm{~cm}$ in length and $14.18 \pm 5.75 \mathrm{~g}$ in weight and lowest (765.48) from a fish measuring $11.65 \pm 1.32 \mathrm{~cm}$ in length and $5.70 \pm 1.45 \mathrm{~g}$ in weight.

The trends of relationships between fecundity and length of the fish, between fecundity and weight of the fish and between fecundity and weight of ovary have been examined (Fig. 6a-c). In M. pancalus the relationship between fecundity (F) and total length (L), body weight (W) and ovary weight (OW) were derived as follows:

$$
\begin{aligned}
& \log F=1.91+0.962 \log L(r=0.252) \\
& \log F=2.57+0.425 \log W(r=0.415) \\
& \log F=3.12+0.318 \log O W(r=0.781)
\end{aligned}
$$

\begin{tabular}{|c|c|c|c|c|c|}
\hline Months & Mean body length $(\mathrm{cm})$ & Mean body weight (g) & Mean ovary weight (g) & Mean absolute fecundity & Mean relative fecundity \\
\hline Jan & $12.80 \pm 0.99$ & $7.68 \pm 1.20$ & 0.01 & Spent & - \\
\hline Feb & $13.14 \pm 1.03$ & $14.89 \pm 3.66$ & $0.29 \pm 0.17$ & $845.2 \pm 198.78$ & $57.9 \pm 11.8$ \\
\hline Mar & $11.65 \pm 1.32$ & $5.70 \pm 1.45$ & $0.10 \pm 0.03$ & $765.48 \pm 231.68$ & $116.23 \pm 11.53$ \\
\hline Apr & $12.11 \pm 1.51$ & $7.54 \pm 2.70$ & $0.55 \pm 0.32$ & $1146.47 \pm 750.3$ & $151.58 \pm 62.49$ \\
\hline May & $13.63 \pm 1.37$ & $9.52 \pm 2.73$ & $0.53 \pm 0.23$ & $1032.2 \pm 364.23$ & $117.97 \pm 50.48$ \\
\hline Jun & $12.91 \pm 1.70$ & $7.73 \pm 2.03$ & $0.62 \pm 0.36$ & $819.43 \pm 434.43$ & $111.93 \pm 41.15$ \\
\hline Jul & $13.38 \pm 2.18$ & $10.70 \pm 3.90$ & $0.84 \pm 0.54$ & $1427.68 \pm 411.91$ & $152.17 \pm 44.73$ \\
\hline Aug & $15.54 \pm 2.58$ & $14.18 \pm 5.75$ & $0.93 \pm 0.69$ & $1691.96 \pm 932.1$ & $138.41 \pm 68.31$ \\
\hline Sep & $13.12 \pm 2.47$ & $8.92 \pm 3.59$ & $0.28 \pm 0.14$ & $682.50 \pm 100.12$ & $141.08 \pm 19.30$ \\
\hline Oct & $13.78 \pm 1.53$ & $10.59 \pm 3.09$ & $0.15 \pm 0.11$ & $750.0 \pm 105.71$ & $83.59 \pm 27.99$ \\
\hline Nov & $13.07 \pm 0.51$ & $9.08 \pm 1.04$ & $0.03 \pm 0.01$ & Spent & - \\
\hline Dec & $13.68 \pm 0.41$ & $9.87 \pm 1.37$ & $0.06 \pm 0.01$ & spent & - \\
\hline
\end{tabular}

Table 8. Monthly variations in fecundity of M. pancalus (mean \pm S.D.) 


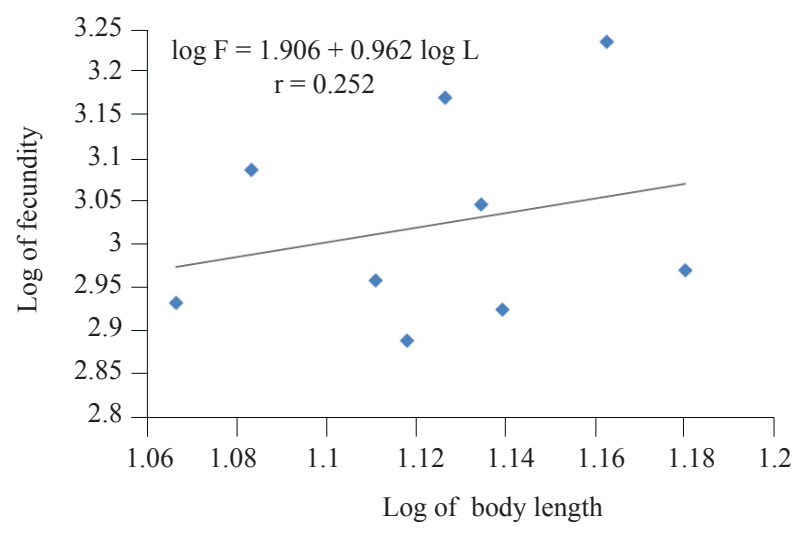

(a)

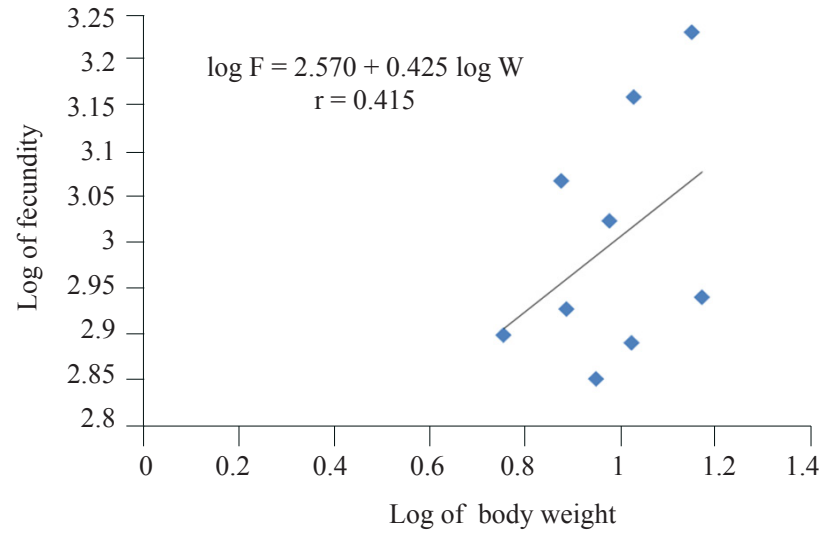

(b)

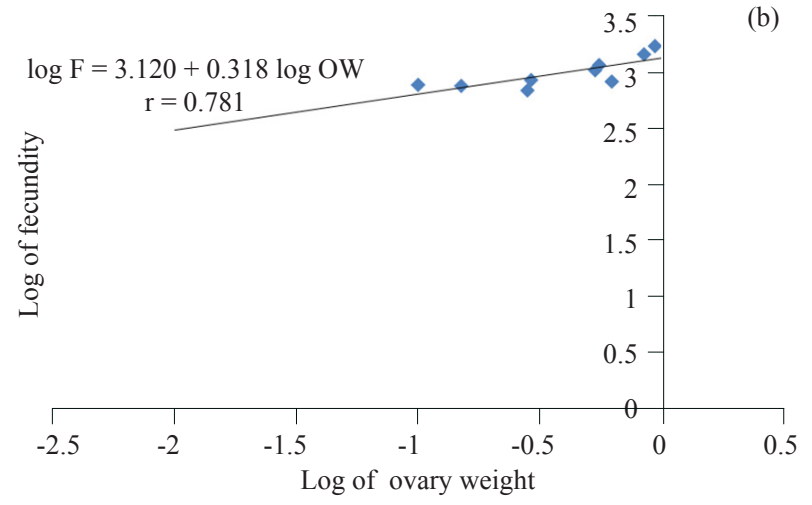

(c)

Fig. 6. Relationship between (a) fecundity and fish length, (b) fecundity and fish weight and (c) fecundity and ovary weight in M. pancalus

Fecundity is one of the important indicators of reproductive potential of the species. Estimation of fecundity is a prerequisite not only in assessing the stock and life history of the species, but also in developing successful breeding programmes (Hyndes et al., 1992; Pankhurst, 1998). In the present study, the low fecundity observed could be attributed to prolonged breeding season or parental care. Similar findings were also reported in Macrognathus aral (Abujam and Biswas, 2011).

The fecundity of a species depends on size of eggs and high fecundity is often correlated with small egg size and vice versa (Rath, 2000). Higher fecundity in M. pancalus was observed in larger specimens, with fecundity increasing with increase in length and weight of fish. The observations of the present study are quite similar to the findings by Narejo et al. (2002) in M. armatus and Suresh et al. (2006) in M. pancalus. Fecundity was moderately high during April/May to August/September in the species. Variations in fecundity are very common in fishes and the number of ova or eggs spawned by an individual female of the fish is dependent on various factors like size, age, species and their ecological habitats including food availability (Fagade et al., 1984; Moyle and
Cech, 2000; Annappaswamy et al., 2008). The estimation of relative fecundity aids in reducing the influence of body size on fecundity of fish, allowing comparison among individuals of different sizes.

In the present study, a straight line relationship for fecundity with body weight, body length and ovary weight was recorded. Further, it reveals that fecundity-body weight and fecundity-body length provides a better relationship as compared to fecundity-ovary weight. Pathak and Jhingran (1977) also reported a straight line relationship between fecundity-total length and between fecunditytotal fish weight in Labeo calbasu while Panek and Coefield (1978) reported a straight line relationship for log of fecundity-length and fecundity-weight in Lepomis sp., Similar findings were also reported in Heteropneustes fossilis (Das et al., 1989), Clarius batrachus (Faruq et al., 1996) and in Gudusia chapra (Kabir et al., 1998). In the present study, correlation coefficient (r) indicated a close relationship between fecundity and ovary weight than fecundity-body weight and fecundity-body length. Low ' $r$ ' values have also been reported in length-fecundity and weight-fecundity relationships in hilsa of Indus River (Islam and Talbot, 1968) and in triggerfish Sufflamen fraenatus (Sahayak, 2005). 


\section{Spawning season}

Morphological changes in the gonads of both sexes, development of the ova and the increase/decrease in GSI values were indicators of spawning season (Fig. 7). Spawning of $M$. pancalus occurs once a year from sexual maturity onwards and all mature eggs or ova were released during the spawning season. Mature and ripe ova were encountered in the species during May and August. Further, the gonads abruptly reduced in size and finally shrunk from September/October onwards. This also indicated that spawning completed by October. GSI also abruptly declined thereafter in spent fish during October to January. GSI increased from March to August with peak in June and GSI remained relatively low during winter until February and then increased gradually. It may be inferred that $M$. pancalus has a prolonged breeding season extending from May to August and even continued upto September. It was clearly observed that spiny eel spawned once in a year with one peak spawning during May to August.

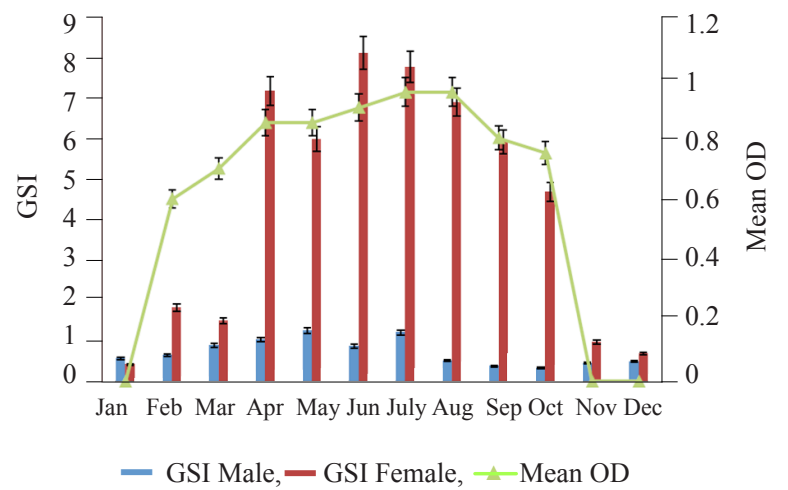

Fig. 7. Monthly variations in the GSI values and ovadiameter in M. pancalus

Nabi and Hossain (1996) also observed single spawning season from May to July for M. aculeatus. Al Mukhtar et al. (2006) pointed out that increase in body weight could be correlated with increase in gonadal size and higher GSI, closer to spawning periods.

Results of the study clearly indicated a prolonged breeding season for $M$. pancalus spanning between May and September. The fecundity further, reveals that the species is moderately fecund and spawns once in a year with a peak spawning during June to August. The information generated is expected to provide a positive tool for the future domestication, artificial propagation and conservation of $M$. pancalus.

\section{Acknowledgements}

The authors are thankful to the Ministry of Environment and Forests, Govt. of India (Project No.
14/45/2005-ERS/RE) for financial support and also to the Department of Life Sciences, Dibrugarh University, Assam for providing necessary facilities to carry out the work.

\section{References}

Abujam, S. K. S. and Biswas, S. P. 2011. Studies on the reproductive biology of spiny eel, Macrognathus aral (Bloch and Schneider) from upper Assam. J. Environ. Biol., 32: 635-639.

Al-Mukhtar, M. A., Al Noor, S. S. and Saleh, J. H. 2006. General reproductive biology of Brunei (Barbus sharpeyi Gunther, 1874) in Al Huwaizah Marsh, Basra-Iraq. Turk. J. Fish. Aquat. Sci., 6: 149-153.

Al-Nahdi, A., Al-Marzouqi, A., Jayabalan, N. and Al-Habsi, S. 2010. Maturation and spawning of the small spotted grunt Pomadasys commersonnii (Lacepede, 1801) in the Arabian Sea off Oman. Int. J. Mar. Sci., 27(1): 67-79.

Annappaswamy, T. S., Reddy, H. R. V. and Nagesh, T. S. 2008. Reproductive biology of Indian sandwhiting, Sillago sihama (Forskal) from estuaries of Dakshina Kannada, South-west coast of India. J. Inland Fish. Soc. India, 40(1): 44-49.

Bagenal, T. B. 1978. Aspects of fish fecundity. In: Gerking, S. D. (Ed.), Ecology of freshwater fish production, Wiley, New York, USA, p. 75-101.

Bagenal, T. B. and Braum, E. 1978. Eggs and early life history. In:IBPHandbook. Methods for assessment of fish production in freshwaters. Blackwell Scientific Publications, p. 165-201.

Biswas, S. P. (1993). Manual of methods in fish biology. South Asian Publishers Pvt. Ltd., New Delhi, India.

Das, M., Dewan, S. and Debnath, S. C. 1989. Studies on fecundity of Heteropneustes fossilis (Bloch) in a mini pond of Bangladesh Agriculture University, Mymensingh, Bangladesh. J. Agric. Sci., 16: 1-6.

El-Halfawy, M. M. 2004. Reproductive biology of Mugil seheli (Family Muglidae) reared in fish farm. Egypt. J. Aqua. Res., 30(B): 234-240.

Fagade, S. O., Adebisi, A. A. and Atanda, A. N. 1984. The breeding cycle of Sarotheondon galilaeus in the IITA Lake, Ibadan, Nigeria. Arch. Hydrobiol., 100: 493-500.

Faruq, M. A., Amin, M. R., Rahmatullah, S. M. and Miah, M. I. 1996. The fecundity of Clarias batrachus (Linnaeus) and the relationship of fecundity with length and weight. Bangladesh J. Fish. Res., 19: 67-70.

Fisher, R. A. 1970. Statistical methods for research workers. $14^{\text {th }}$ edn. Oliver and Boyd, Edinburgh, UK.

Froese, R. and Pauly, D. 2006. Fish Base, World-wide Web Electronic Publication. http://www. fishbase.org. (Accessed 12 March 2018). 
Grimes, C. B. and Huntsman, G. R. 1980. Reproductive biology of vermilion snapper, Rhomboplites aurorubens from North Carolina and South Carolia. Fish. Bull., 78: 137-146.

Hodgkiss, I. J. and Mann, H. S. M. 1978. Reproductive biology of Saratherodon mossambicus (Cichlidae) in Plover Cove Reservoir, Hong Kong. Environ. Biol. Fish., 3(3): 287-292.

Hopkins, C. L. 1979. Reproduction in Galaxias fasciatus Gray (Salmoniformes: Galaxiidae). New Zeal. J. Mar. Fresh. Res., 13(2): 225-230. DOI: 10.1080/00288330.1979.9515797.

Hyndes, G. A., Neira, F. G. and Potter, I. C. 1992. Reproductive biology and early life history of the marine teleost Platycephalus speculator Klunzinger (Platycephalidae) in a temperate Australian Estuary. J. Fish Biol., 40: 859-874. doi.org/10.1111/j.1095-8649.1992.tb02632.x.

Islam, M. N. 2004. Eco-biology of freshwater gobi, Glossogobius guiris (Hamilton) of the River Padma in relation to its fishery: A review. J. Biol. Sci., 4(6): 780-793. DOI: $10.3923 /$ jbs.2004.780.793.

Islam, B. N. and Talbot, G. B. 1968. Fluvial migration, spawning and fecundity of the Indian river hilsa Tenualosa ilisha. Trans. Am. Fish. Soc., 97: 350-355. doi.org/10.1577/15488659(1968)97[350:FMSAFO]2.0.CO;2.

Kabir, A. K., Hossain, M. A., Rahmatullah, M. A., Dewan, S. M. S. and Islam, M. S. 1998. Studies on the gonadosomatic index and fecundity of chapila (Gudusia chapra Ham.). Bangladesh J. Fish. Res., 2: 195-200.

Komolafe, O. O. and Arawomo, G. A. O. 2007. Reproductive strategy of Oreochromis niloticus (Pisces: Cichlidae) in Opa Reservoir, IIe-Ife, Nigeria. Rev. Biol. Trop. (Int. Trop. Biol.), 55(2): 595-602. DOI: 10.15517/rbt. v55i2.6034.

Lakra, W. S. and Sarkar, U. K. 2006. Evaluation of fish biodiversity of Eastern Ghats region for conservation and Sustainable utilization. EPTRI-ENVIS Newsletter, 12(3): 2-7.

Lelek, A. 1993. Sequence of changes in fish population in the new tropical manmade Lake Kainji, Naigeria, West Africa. Arch. Hydrobiol., 71: 381-420.

Karim, M. A. and Hossain, A. 1972. Studies on the biology of Mastacembelus pancalus (Ham.) in artificial ponds. Part II. Sexual maturity and fecundity. Bangladesh J. Biol. Agricul. Sci., 1: 15-18.

Moyle, P. B. and Cech, J. J. 2000. Reproduction. in fishes: An introduction to ichthyology, $4^{\text {th }}$ edn., Prentice Hall Inc, USA, p. 123-144.

Nabi, M. R. and Hossain, M. A. 1996. Reproductive biology of the fresh-water spiny eel Macrognathus aculeatus (Bloch). Bangladesh J. Zool., 24: 115-120.
Narejo, N. T., Rahmatullah, S. M. and Rashid, M. M. 2002. Studies on the reproductive biology of freshwater spiny eel, Mastacembelus armatus (Lacepede) reared in the cemented cisterns of BAU, Mymensingh, Bangladesh. Pakistan J. Biol. Sci., 5(7): 809-811. DOI: 10.3923/pjbs.2002.809. 811.

Nautiyal, P. and Lal, M. S. 1985. Fecundity of the Garhwal Himalayan mahseer, Tor putitora (Hamilton). J. Bombay Nat. Hist. Soc., 82(2): 253-257.

Nelson, J. S. 1994. Fishes of the world, $3^{\text {rd }}$ edn. John Wiley \& Sons, New York, USA.

Panek, M. F. and Cofield, C. R. 1978. Fecundity of bluegill and warmouth from a South Carolina Black Water Lake. Prog. Fish Cult., 40: 67-68. doi.org/10.1577/1548-8659(1978) 40[67:FOBAWF]2.0.CO;2.

Pankhurst, N. W. 1998. Reproduction. In: Kenneth Black and Alan D. Pickering, (Eds.), Biology of farmed fish, Sheffield Accademic Press Ltd., UK, p. 1-26.

Pathak, S. C. and Jhingran, A. G. 1977. Maturity and fecundity of Labeo calbasu (Ham.) of Loni Reservoir, M. P. J. Inland Fish. Soc. India, 9: 92-93.

Qasim, S. Z. 1973. An appraisal of the studies on maturation and spawning in marine teleost from Indian water. Indian $J$. Fish., 20: 166-181.

Raje, S. G. 2006. Some aspects of biology of catfishes Tachysurus caelatus (Valenciennes) and Osteogeneiosus militaris (Linnaeus) from Mumbai. Indian J. Fish., 53(3): 333-340.

Rath, R. K. 2000. Freshwater aquaculture, $2^{\text {nd }}$ edn. Scientific Publication, Jodhpur, India.

Ramon, D. and Bailey, K. 1996. Spawning seasonality of albacore, Thunnus alalunga, in the South Pacific Ocean. Fish. Bull., 94(4): 725-733.

Sahayak, S. 2005. Reproductive biology of the masked triggerfish Sufflamen fraenatus. J. Mar. Biol. Ass. India, 47(1): 70-76.

Suresh, V. R., Biswas, B. K., Vinci, G. K. and Mukherjee, A. 2006. Biology and fishery of barred spiny eel, Macrognathus pancalus Hamilton. Acta Ichthyol. Pisc., 36(1): 31-37.

Swarup, K., Srivastava, S. and Das, V. K. 1972. Sexual dimorphism in the spiny eel, Mastacembelus pancalus. Curr. Sci., 41(2): 68-69.

Talwar, P. K. and Jhingran, A. G. 1991. Inland fishes of India and adjacent countries, vol. 2. Oxford and IBH Publishing, New Delhi, India.

Tripathi, S. D. 2004. Ornamental fishes: Breeding, culture and trade. In: Das, R. C., Sinha, A., Datta, S. and Ghose, S., (Eds.), Proceedings of the National Seminar on Prospects of Ornamental Fish Breeding and Culture in Eastern and 
North-eastern India. ICAR-Central Institute of Fisheries Education, Kolkata, India, p. 17-42.

Vinci, G. K., Suresh, V. R. and Bandyoppadhyaya, M. K. 2005. Biology of Gudusia chapra (Hamilton-Buchanan) from a floodplain wetland in West Bengal. Indian J. Fish., 52(1): 73-79.

Wu, C. L. and Kuo, C. L. 1993. Maturity and fecundity of albacore from the Indian Ocean. J. Fish. Soc. Taiwan, 20(2): 135-152. 